\title{
Mark and Matthew I
}

\author{
Comparative Readings: Understanding the Earliest Gospels in their First Century \\ Settings \\ Ed. by Eve-Marie Becker and Anders Runesson
}

[Markus und Matthäus - vergleichende Analysen. Die frühesten Evangelien im Kontext des ersten Jahrhunderts.]

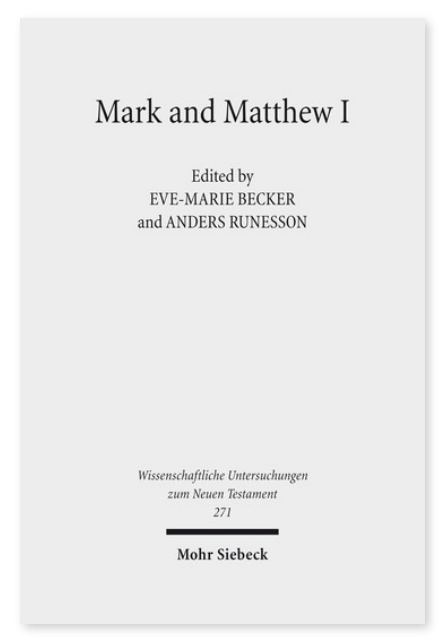

2011. IX, 491 Seiten. WUNT I 271

ISBN 978-3-16-151560-6

DOI 10.1628/978-3-16-151560-6

eBook PDF 159,00€

ISBN 978-3-16-150837-0

Leinen $159,00 €$
Veröffentlicht auf Englisch.

Die vergleichende Analyse des Markus- und des Matthäusevangeliums hat eine lange Tradition. Seit sich die Theorie von der Priorität des Markusevangeliums in der ersten Hälfte des 19. Jahrhunderts durchgesetzt hat, konzentrieren sich viele Untersuchungen lediglich auf jeweils eines der beiden Evangelien. Dabei steht häufig das eine der beiden Evangelien im Schatten des anderen. Im Unterschied dazu untersuchen die Autorinnen und Autoren der Beiträge, die in diesem Band gesammelt sind, die Evangelien vom Ansatz her vergleichend: Sie wählen unterschiedliche methodische Fragestellungen, um die Evangelientexte im Kontext ihrer Entstehungszeit zu betrachten. Damit tragen sie gleichzeitig zur Diskussion über das synoptische Problem bei und erweitern die Perspektive der herkömmlichen Synoptiker-Forschung um neue Erkenntnisse. Indem sie bisher unbeachtete Aspekte der Evangelienexegese beleuchten, bereichern sie unser Verständnis der literarischen Genese beider Evangelien im ersten Jahrhundert.

Inhaltsübersicht

Eve-Marie Becker and Anders Runesson: Introduction: Studying Mark and Matthew in Comparative Perspective 1. History of Research

Cilliers Breytenbach : Current Research on the Gospel according to Mark: A Report on Monographs Published from 2000-2009 - David C. Sim : Matthew: The Current State of Research

2. Reconstructing the Artifacts: Text-Critical and Linguistic Aspects of the Study of Mark and Matthew Barbara Aland: Was heißt Abschreiben? Neue Entwicklungen in der Textkritik und ihre Konsequenzen für die Überlieferungsgeschichte der frühesten christlichen Verkündigung - Tommy Wasserman: The Implications of Textual Criticism for Understanding the 'Original Text' - Stanley E. Porter: Matthew and Mark: The Contribution of Recent Linguistic Thought

3. Date and Genre

Eve-Marie Becker: Dating Mark and Matthew as Ancient Literature - David E. Aune : Genre Theory and the Genre-Function of Mark and Matthew

4. Socio-Religious Location

Sean Freyne: Matthew and Mark: The Jewish Contexts - Morten Hørning Jensen : Conflicting Calls? Family and Discipleship in Mark \& Matthew in the Light of First-Century Galilean Village Life - Linden Youngquist: Matthew, Mark and Q - Wayne Baxter : Matthew, Mark, and the Shepherd Metaphor: Similarities, Differences, and Implications

5. Conflict and Violence

Warren Carter: Matthew: Empire, Synagogues, and Horizontal Violence - Lorenzo Scornaienchi : The Controversy Dialogues and the Polemic in Mark and Matthew - John S. Kloppenborg: The Representation of Violence in Synoptic Parables 6. Building Community Using Text

Oda Wischmeyer: Forming Identity Through Literature: The Impact of Mark for the Building of Christ-Believing Communities in the Second Half of the First Century C. E. - Anders Runesson: Building Matthean Communities: The Politics of Textualization 7. Notes from the Conference: Further Discussion

Adela Yarbro Collins : Reflections on the Conference at the University of Aarhus, July 25-27, 2008

Eve-Marie Becker Geboren 1972; 2001 Dr. theol.; 2004 Habilitation; 2006-18 Professorin für neutestamentliche Exegese an der Universität Aarhus/Dänemark; 2016-17 Distinguished Visiting Professor of New Testament an der Emory University in Atlanta/USA; seit 2018 Professorin für Neues Testament an der Westfälischen Wilhelms-Universität Münster. https://orcid.org/0000-0002-0398-6448

Anders Runesson Born 1968; 2001 PhD; 2002 Docent, Lund University, Sweden; 2003-15 Professor of Early Christianity and Early Judaism, McMaster University, Canada; since 2015 Professor of New Testament in the Faculty of Theology at the University of Oslo, Norway.

https://orcid.org/0000-0001-6042-0101

Jetzt bestellen:

https://mohrsiebeck.com/buch/mark-and-matthew-i-9783161515606?no_cache=1

order@mohrsiebeck.com

Telefon: +49 (0)7071-923-17

Telefax: $+49(0) 7071-51104$ 